How to cite this article:

Bakhshandeh, F., Kazemi, H., \& Tooranloo, H. S. (2020). Development of the sustainable entrepreneurship model. Malaysian Management Journal, Vol. 24(July), 103-143. https://doi.org/10.32890/mmj.24.2020.9362

\title{
DEVELOPMENT OF THE SUSTAINABLE ENTREPRENEURSHIP MODEL
}

\author{
FATEMEH BAKHSHANDEH \\ HOSSEIN KAZEMI \\ Faculty of Management \\ Vali-e-Asr University of Rafsanjan, Rafsanjan, Iran \\ HOSSEIN SAYYADI TOORANLOO \\ Faculty of Management, Meybod University, Meybod, Iran \\ Corresponding author: hkazemi1384@yahoo.com
}

\begin{abstract}
The most prominent feature of today's economy is rapid change. To succeed in such an economy, countries must be able to adapt to these changes with great agility. One of the most potent tools for achieving this end is sustainable entrepreneurship. Sustainable entrepreneurs are those who undertake entrepreneurial endeavors while taking into account different aspects of social, economic and environmental sustainability. These entrepreneurs strive to keep their resources focused on sustainable development and to balance the objectives of entrepreneurial success and sustainability so as to solve social and environmental problems. In this study, after reviewing the research literature and identifying the factors pertinent to sustainable entrepreneurship, a conceptual model was developed by drawing on the expertise of 10 experts, who were selected by snowball sampling. Interpretive Structural Modeling (ISM) approach was used to examine the network of relationships among the factors. The findings showed that the considered factors fall into four levels: sustainability culture was placed at the most fundamental level, legal requirements, resource preservation, social participation, green management and human resources management were placed at the second level, social justice, effective and efficient processes, and customer-centricity were placed at the third level, and social well-being
\end{abstract}


and economic benefits were identified as the top-level factors or outputs of sustainable entrepreneurship. The proposed model depicted means, process, first order and ultimate goal in inhacing entrepreneurship sustainability endeavors.

Keywords: Entrepreneurship, sustainable entrepreneurship, ISM (Interpretative Structural Modeling).

Received: 24/3/2020 Revised: 5/8/2020 Accepted: 6/7/2020 Published: 30/8/2020

\section{Introduction}

Recent decades have witnessed major developments in the areas of communications, trade, and business competition at the global level. To cope with these developments, many businesses are now required to constantly keep their business plans, products, and services up-to-date. This need has enhanced the importance of creativity and innovation to produce new products and services through novel methods and processes (Gibb, 2005; Hall, Daneke \& Lenox, 2010; Lee, Wong, Der Foo \& Leung, 2011). entrepreneurship and there is ample evidence suggesting that entrepreneurship is a major driver of economic growth in developed countries (Wennekers, Van Stel, Carree \& Thurik, 2010).

In today's world, the spirit of entrepreneurship and the ambition to establish and develop new businesses are essential for the economic stability and dynamism of countries (Lindholm Dahlstrand, 2007; Saarenketo, Puumalainen, Kuivalainen \& Kyläheiko, 2009). The importance of entrepreneurship must be attributed to its role in enhancing economic efficiency, motivating innovation in labor and production markets, creating new job opportunities, and seizing the emerging business opportunities (Shane \& Venkataraman, 2000; Urbano, Toledano, \& Soriano, 2010). Entrepreneurship, as a solution for overcoming the challenges and obstacles of human development, is an extensively discussed and debated subject. Many researchers see entrepreneurship as the driving force behind human development and consequently economic growth (Carter, 2005).

Another issue of pertinence to economic growth is sustainable development. Sustainable development initiatives are global efforts to ensure continuity and dynamism in economic growth, social justice in development, and preservation of environmental capacities not only for the present but also for future generations. This concept represents a holistic viewpoint and commitment to improving the common future of all humans (Abdollahzadeh 
\& Sharifzadeh, 2014). The primary justification for following this path to development is to control its environmental and social impacts; however, sustaining development is also known to enhance the economic performance of businesses and institutions (Engert \& Baumgartner, 2016; Epstein \& Roy, 2001; Saunila, Nasiri, Ukko, \& Rantala, 2019).

Since 1970, sustainability has been extensively promoted as a goal and strategy with a focus on merging welfare and social justice objectives with a wider set of objectives concerning the environment (Moore, 2004). In other words, the purpose of the concept of sustainable development is to make sure that the problem of distributing limited natural resources and the need to improve human welfare are discussed within the same framework (Bunch, Johnson, \& Robert, 2008). In this regard, entrepreneurs can be encouraged to search for innovations that produce sustainable products and services. The concept of sustainable entrepreneurship has been proposed to represent the entrepreneurship that is mindful of the need to protect biological, social and economic resources (Abdollahzadeh \& Sharifzadeh, 2014).

Sustainable entrepreneurship is an integration of sustainable planning and entrepreneurship that enhances social capital as well as business value (Schaltegger \& Wagner, 2011). Sustainable entrepreneurship focuses on the concept of creativity in entrepreneurship as a driving force for developing a comprehensive and sustainable economic, environmental, and social system (Shepherd \& Patzelt, 2011). Sustainable entrepreneurship has been described as the process of creating a business opportunity based on the recognition of individual and group skills that are needed to interact with and adapt to environmental resources in a constructive way (Buysse \& Verbeke, 2003; Klewitz \& Hansen, 2011). Analysis of the components and features of sustainable entrepreneurship in different societies is of immense importance for promoting this concept, as this area holds many challenges as well as opportunities for entrepreneurs, and overcoming these challenges and seizing these opportunities is crucial for the development of sustainable innovative solutions for future markets (Hockerts \& Wüstenhagen, 2010). In this regard, the present study aims to develop a comprehensive model of the components and criteria of sustainable entrepreneurship in economic, social and environmental dimensions.

\section{Literature Review}

\section{Entrepreneurship}

Entrepreneurship is an old and fundamental concept in economic theories (Seelos \& Mair, 2005). The term entrepreneurship is derived from the French 
word "entreprendre", which means to undertake and was first coined by Richard Cantillon (Rotheroe \& Richards, 2007). A review of the history of entrepreneurship literature shows that this term was first used by economists in economic theories and then introduced into other fields. Outlining an exact definition for the concept of entrepreneurship is an important first step for any research in this area (Shane \& Venkataraman, 2000). In essence, entrepreneurship is an interdisciplinary concept that has evolved under influence from various fields including economics, psychology, anthropology, sociology and management (Johnson, Parker \& Wijbenga, 2006). Entrepreneurship is largely viewed as a symbol of striving to succeed which is a source of major developments in production, service and industry and an engine of economic growth, job creation and social reform (Greco \& De Jong, 2017; Urbano, Toledano \& Soriano, 2010).

Some scholars view entrepreneurship as a multidimensional structure encompassing novel enterprises, innovation in products and processes (Finlay-Robinson, 2013), self-learning, risk-taking, competition, and utilising critical catalysts, effective strategies, and innovative procedures to achieve sustainable goals (Baruah \& Ward, 2015; Widya-Hastuti, Talib, Wong \& Mardani, 2016; Zhao, 2005). Entrepreneurship has also been described as an attitude that encourages people to turn their creative ideas into a business (Zahra, 2005). Entrepreneurship creates social value through the discovery of job opportunities and is a function of communication and management that controls financial, human and material resources (Nacu \& Avasilcăi, 2014).

The entrepreneurs are widely acknowledged as agents of change in the business world as they detect opportunities that others easily miss or see as a problem (Alipour, Shaghagh, \& BARGHI, 2012). Entrepreneurship is rightfully prized as a valuable quality because societies can no longer rely on traditional methods to achieve their economic objectives and compete efficiently (van Dam, Schipper, \& Runhaar, 2010).

\section{Sustainability}

Sustainability has been one of the key terms of economic and social policy since the second half of the twentieth century. In a broad sense, it refers to the process of social change and transformation of the national economy, especially in developing countries (Hall, Daneke \& Lenox, 2010). The word sustainability is rooted in forestry and was first used in 1713 in a book titled "Sylvicultura Oeconomica" to explain this simple principle that to preserve the forest, one should control the harvesting of wood (Fischler, 2014). After 
many decades of focus on the social aspects of sustainability, the release of a report titled "Our common future" by the World Commission on Environment and Development (WCED) in 1987expanded this discussion to how sustainable development can be achieved in both business and society (Barthelme, 2017).

Indeed, the modern definition of sustainability was introduced in WCED's "our common future" reports, which explicitly outlined the principles of sustainable development (Hinrichsen, 1987). In this report, sustainable development has been defined as the "development that meets the needs of the present without compromising the ability of future generations to meet their own needs" (Shepherd \& Patzelt, 2011). This definition of sustainability has three dimensions: environmental, economic and social (Hopwood, Mellor \& O'Brien, 2005). Naturally, the quest for ensuring our social and economic well-being both at present and in the future is linked to the well-being of the planet. As a result, the three dimensions of sustainable development, namely economic growth, environmental protection, and social development, are codependent (Károly, 2011). Since the overuse of fossil fuels has led to an array of local and global problems including air and environmental pollution, thinning of the ozone layer, loss of biodiversity, and most importantly, greenhouse gas emission and consequent global warming (IPCC, 2007), environmental protection has overshadowed other objectives of sustainable development in terms of immediate importance (Belz \& Binder, 2017). Environmental sustainability can be defined as the management of changes in technology, production, and service delivery processes in line with the environmental goals of sustainability (Wiesner, Chadee \& Best, 2018). Environmental sustainability requires us to make rational, coherent and transparent decisions about our patterns of consumption and production not according to a fixed near-term horizon but consistently and over the long term (Bhar, 2017).

Social sustainability is not a well-defined concept and has received little attention in the literature. This dimension of sustainability was brought to attention when scholars started to discuss legal, security, and health aspects of sustainability rather than its cultural and ethical implications (Hutchins \& Sutherland, 2008). Social capital and social development are basic necessities to fostering sustainable development. To maintain social sustainability, it is important to augment social capital and generate resources necessary to empower disadvantaged citizens (García, Eizaguirre \& Pradel, 2015). On the one hand, social sustainability is fundamentally associated with social justice or equality as an essential part of the way to improve human life (Trudeau, 2018). On the other hand, social sustainability is also concerned with the sustainability of society and the creation of social values. This 
aspect of social sustainability also emphasises the guarantee of life priorities, quality of life, social stability, security and social participation (Vallance, Perkins, \& Dixon, 2011). Another aspect of sustainable development is economic sustainability. Economic sustainability is indeed dependent on social sustainability given that an individual's well-being and security are associated with the well-being and security of society and features such as social integration, participationx and tolerance enhance the people's sense of responsibility (Shepherd \& Patzelt, 2011). Economic sustainability is the generation and maintenance of long-term and sustainable income for society and its members without overexploiting reserves and capitals. In other words, the economy will remain stable as long as its natural, social and human systems are left undamaged. Overall, sustainable economic development is an essential catalyst for sustainable development (Aboagye, 2017).

\section{Sustainable Entrepreneurship}

The most prominent feature of today's economy is rapid change. To succeed in such an economy, countries must be able to adapt to these changes. One of the most potent tools for achieving this end is sustainable entrepreneurship (Fischer, Mauer, \& Brettel, 2018). Sustainable entrepreneurship has been defined as the act of recognition, development and exploitation of opportunities to create goods and services with economic, social and environmental benefits (Mupfasoni, Kessler, \& Lans, 2018). Sustainable entrepreneurs are entrepreneurs who take into account different aspects of social, economic and environmental sustainability in their entrepreneurial endeavors (Tilley \& Parrish, 2006). These entrepreneurs strive to keep their resources focused on sustainable development (Parrish, 2006) and to balance the objectives of entrepreneurial success and sustainability so as to solve social and environmental problems (Schaltegger \& Wagner, 2011). In a way, sustainable entrepreneurs guarantee economic, social and environmental health through entrepreneurial behaviour (Shepherd \& Patzelt, 2011).

Therefore, sustainable entrepreneurs create sustainable products, processes and services that preserve and protect resources, lives and communities. In other words, they use the economic and non-economic gains of their business to the benefit of people, economy and society. These non-economic goals are the features that distinguish sustainable entrepreneurship from traditional entrepreneurship (Shepherd \& Patzelt, 2011). Indeed, sustainable entrepreneurs attempt to create not only a profitable business but also sustainable products and processes with environmental and social goals (Choi \& Gray, 2008). This is a distinct branch of entrepreneurship where entrepreneurs are moving towards a sustainable economic environment that promises the greatest opportunity for investment and invention in the 
industrialised world (Dean \& McMullen, 2007). Sustainable entrepreneurship also encompasses some aspects of social responsibility whose social benefits go beyond the business (McWilliams \& Siegel, 2001). Attention to social and environmental threats is at the heart of sustainable entrepreneurship because it sees them as the origin of emerging investment opportunities (Dean \& McMullen, 2007; York \& Venkataraman, 2010).

The purpose of this study is to identify the characteristics and features of sustainable entrepreneurship. Therefore, the factors of sustainable entrepreneurship in the research literature are discussed in the following.

Social well-being: One group of theories that have greatly influenced the evolution of perceptions of well-being in the second half of the 20th century is social theories that pay attention to the qualitative aspects of sustainable development which today fall in the framework of quality of life. Since the introduction of this concept, the social well-being has attracted the attention of scientific and research communities and has been the subject of numerous scientific conferences and assemblies which have only added to the importance of this concept at the world stage (Schyns \& Boelhouwer, 2004).

Social well-being is a very popular topic of discussion and is often discussed in the daily conversation of citizens about their personal expectations and needs. Therefore, as mentioned in the report of the United Nations (1992), one of the first processes in the movement toward sustainability is to take action in support of social well-being (Lepage, 2009). This is because for a society to move toward economic and human development, its members should enjoy full health and long life to contribute to that society (Setboonsarng \& Gregorio, 2017). Social well-being is an individual's perception of his/her status in society as regards to the provision of environmental/human health services, safety against environmental threats and attention to psychological needs. One of the key components of social well-being is environmental/ human health, which can be defined as the health of people's lives in a specific environment (Janušauskaitè, Nolan \& Whelan, 2003). Another noneconomic benefit of sustainable entrepreneurship is the acknowledgment of people's psychological and emotional needs (Gallo \& Matthews, 2003), which means recognising the importance of mental health in addition to physical health and environmental health (Macke, Casagrande, Sarate \& Silva, 2018). Although entrepreneurial endeavours cannot accommodate all of the material needs of citizens, entrepreneurs can help improve the lives of citizens by providing new goods and services and preventing market failures. Since markets are unable to meet some of the citizens' needs, this 
contribution of entrepreneurship to meeting the neglected and non-market needs of citizens is important for the betterment of social well-being. In this context, market failure means the inability of the market to produce potential benefits through the exchange of goods and services (Zerbe Jr \& McCurdy, 2000).

Sustainability culture: Culture is an important aspect of society and the preservation of good cultures enables people to form a foundation for a well-developed society (Margalit \& Halbertal, 2004). Nurturing of sustainability culture and sustainable social values, such as trust, is important for resilience and sustainability of societies (Shepherd \& Patzelt, 2011). Building up sustainability culture by establishing an inclusive network and incorporating it within the organisational culture are among the activities that help entrepreneurs develop a sustainable business. Cultural promotion in organisations and societies is an important factor for achieving sustainable entrepreneurship. In other words, the reinforcement of cultural elements and values that encourage sustainability is an important step in the area of sustainable development of businesses (Bell \& Stellingwerf, 2012). The culture of a society is a conglomerate of its shared values, norms and characteristics which make it unique and shapes its overall identity. By preserving their culture, people of a community can maintain their personal identity which results in increased dignity and human rights (Shepherd \& Patzelt, 2011). Culture can also play a role in sustainability by facilitating access to market information and reducing information gaps (Schwartz \& Sendor, 1999). Studies conducted in this area have consistently shown that culture would be an important aspect of any type of business reform to achieve sustainability (Calabrese, Costa, Menichini, Rosati, \& Sanfelice, 2013).

Justice: The promotion of justice is widely acknowledged as one of the key indicators of good governance and a healthy society. Over the years, sustainable development, which was once mostly restricted to the environmental aspect of sustainability, has been extended to the concept of equitable and balanced development. The International Labor Organisation considers social justice as one of the important initiatives to promote sustainable development and has introduced a series of standards for support and promotion of justice (Muñoz \& Dimov, 2015).

Justice is the basis of a healthy society, where all social, economic, environmental and cultural factors contribute to its stability and flexibility. Hence, an ideal society must continuously integrate the economic, environmental and social aspect of sustainable development in such a way as to improve human well-being and justice in society (Korten, 2010). 
The United Nations views sustainable entrepreneurship as a cost-effective long-term business endeavour or investment that promotes environmental protection and social justice (Greco \& De Jong, 2017). In other words, social justice is an important social structure integral to sustainable entrepreneurship which safeguards the interests and opportunities of future generations (Luo, 2007). In fact, social justice can be used as a metric to assess sustainability (Normann, Ellegaard \& Møller, 2017). In the United Nations report on social justice and sustainable development, this concept is focused on the equitable distribution of income and utilisation of resource (Greco \& De Jong, 2017).

It is widely believed that justice is one of the key dimensions of social sustainability. Social sustainability promotes justice by ensuring equitable distribution of benefits, social justice, gender equality, women empowerment, adequate responding to the needs of low-income families, participation in the development process, contribution to communal decision-making and encouragement of job creation (Oyebanji, Liyanage \& Akintoye, 2017). Another component of justice is the promotion of fair trade. The World Trade Organisation believes that trade must contribute to a sustainable resolution of challenges by expanding opportunities, especially for small and disadvantaged producers. The crises of the global economy and persistent poverty in many countries highlight the need to support and promote fair and sustainable trade at the local and global levels; a trade that supports sustainable practices with minimum damage to the environment (Renard, 2003).

Social participation: Social participation is a multidimensional structure associated with the components of social relations, information networks and social responsibility (Hammel et al., 2008). Some scholars argue that social participation is of immense importance for the stakeholders of businesses because it creates information networks between customers and producers and other agents involved in the business, thus leading to improved relationship and communication between them (Alavi, Kayworth \& Leidner, 2005). One of the main components that can influence social participation is the strengthening of team performance (Merritt \& Snyder, 2014). Social participation should be included in the training processes of the business and be actively promoted in personal interactions to improve communication and collaboration between members of the organisation. Indeed, social participation leads to improved communication between personnel and motivates them to help each other overcome barriers in their area of expertise which results in improved development and dissemination of collective information (Gorman \& Fischer, 2009). WCED has also listed democracy and the freedom of choice as core values that contribute to achieving sustainable development (Shepherd \& Patzelt, 2011). Another 
important factor of sustainable entrepreneurship is communities (Shepherd \& Patzelt, 2011). Communities are complex networks of relationships between a group of people who share certain values, norms, history or identity. As such, communities greatly contribute to the identity of the society and make it distinct from other societies (Etzioni, 1996). In general, social participation is significantly important for strengthening and and enhancing the development of valuable social and cultural resources (Stuber, 2009).

Resource preservation: Nature refers to the phenomena of the physical world including the earth, biological mechanisms and ecosystems (Parris \& Kates, 2003). The intrinsic value of nature is in its role in supporting the life of living organisms (Muehlebach, 2001). In its declaration, WCED has strongly emphasised the need to preserve the beauty of the earth and the importance of protecting natural resources and green spaces (Brundtland, 1987). Conservation and sustainability of human life and living organisms depend on the conservation of environmental resources, ecosystem and biodiversity (Costanza et al., 1997), development of the recycling process (Langstaff \& Brzozowski, 2017) and expansion of forests and green spaces (Dean \& McMullen, 2007). Recent studies have shown that proximity to natural green spaces significantly improves human health (Pretty, Hine, \& Peacock, 2006). Environmental entrepreneurship is a type of entrepreneurial activity that seeks to conserve and improve environmental resources and emphasises the proper use of these resources (Baker \& Nelson, 2005). As a mechanism for nature conservation, sustainable entrepreneurship can help individuals, organisations and nations to find new ways to conserve land, biodiversity and ecosystems (Shepherd \& Patzelt, 2011).

Legal requirements: Research shows that the environmental laws and regulations help reinforce the sustainability of society and businesses. Legal requirements play especially important role in improving the environmental sustainability of businesses when they are geared to not pay much attention to this concept (Cai, Chen, \& Bose, 2013). In fact, legal requirements emphasise the dynamic aspects of sustainability. The core of these requirements is the notion that all natural systems have certain limitations and to sustain welfare, we have to live respecting these limitations (Hall, Daneke, \& Lenox, 2010). Legal requirements regarding environmental sustainability give the business certain capabilities that lead to improved business dynamism and integration which are among the characteristics of sustainable development (Russo \& Fouts, 1997). With the adoption and enforcement of legal rules and requirements such as product labeling (Chavan, 2001), requiring resource use permissions (Thornbush, 2017), quality certification and others, not only some but all individuals and businesses will be required to comply with environmental regulations and requirements. 
Green management: Green management is a development strategy and framework for achieving the objectives of sustainability and clean production (Nawaz \& Koc, 2018), which involves enhancing production and management processes to reduce their environmental impacts (Neutzling, Land, Seuring \& do Nascimento, 2018) and adopting innovative ways of doing business to align profitability around sustainability goals (Alberti \& Varon Garrido, 2017). Studies have shown that green management can generate noteworthy economic, social and environmental value for example by creating a waste recycling strategy. The effort to use less material and redesign production methods and operations based on environmental requirements is another efficient approach to sustainable development (Aras \& Crowther, 2009; Schaltegger \& Burritt, 2010). One of the main strategies of green management is to use green technologies to protect the environment (Simon, Bernardo, Karapetrovic \& Casadesús, 2011); technologies that are intended to utilize scientific knowledge and expertise to promote green manufacturing, which itself can result from the development of economic and environmental sustainability (Ahi \& Searcy, 2013). The use of green technologies is a managerial innovation that can improve production processes and reduce their environmental impacts (Ahi \& Searcy, 2013; Li, Zhao, Zhang, Chen, \& Cao, 2018).

Customer and stakeholders: After the industrial revolution and the emergence of rapidly changing global markets and competition and highly dynamic environments, organizations and businesses were forced to become more competitive and focus more on customer satisfaction. One of the strategies developed to ensure customer satisfaction in businesses and organizations is customer-centricity or customer orientation (Hoffman \& Ingram, 1992). Customer-centricity is the act of lessening to customers and putting them at the center of sales strategy (Christensen, Cook, \& Hall, 2005). Customer-centricity can also be described as the tendency of employees to provide the customers with the best possible service so that they are perfectly satisfied (Lee \& Hwang, 2016). Over the years, there have been many developments in this area, one of the most important of which is the improvement in customer-centricity measurements. This is an important issue because, given the variety of choices and alternatives available to customers, each customer has its own value for the business. This issue is so important that it has found a place at the center of entrepreneurship discussion (Vegholm, 2011). It has been suggested that changing the business attitude from product-centricity towards customer-centricity helps the business establish and nurture lasting relationships with customers, which enhances customer loyalty and ultimately leads to higher profitability for the organisation (Rozek \& Karlicek, 2014). 
Efficient and effective processes: Effective and efficient processes provide the means and infrastructure needed to achieve economic, social, and environmental objectives and affect employees' competence, motivation, and attitude (Figge, Hahn, Schaltegger, \& Wagner, 2002). It has been argued that true sustainability can be achieved only when it is well integrated into major business processes (Smith \& Lenssen, 2008). Identifying stakeholder expectations and incorporating them into business processes requires a systematic approach characterised by planning, resource management, process design and continuous improvement (Svensson et al., 2011). Also, processes provide lifelong learning opportunities for staff and human resources, which is the way to accumulate superior human capital. By creating positive impacts on performance, these processes expand the potential for improving productivity, quality and innovation, and ultimately meeting the expectations of stakeholders, shareholders, customers in the target market (Pinzone et al., 2018). Research and development activities are among the most crucial processes for business innovation and economic growth (Savona, Cainelli \& Evangelista, 2006).

Economic benefits: Economic success has always been a major driver of entrepreneurial activity. Therefore, sustainable entrepreneurship does not mean neglecting the economic benefits of business activity. Entrepreneurship is sustainable if it provides a reasonable level of economic, social and environmental benefit. The economic aspect of entrepreneurship refers to the creation of economic value and how it is distributed among shareholders (Huatuco et al., 2013). The economic aspect encompasses the views of shareholders and typically uses traditional financial metrics such as operating cash flow, return on investment (ROI), and changes in operating income over time (Milis \& Mercken, 2004). In this discussion, one also has to pay attention to the role of financial intermediaries in economic development. In this regard, it has been argued that although technological innovation is a long-term driver of economic growth, the main driver of innovation is the financial support that provides the necessary resources for entrepreneurship (Shumpeter, 1968). Looking at today's competitive business environment, it is obvious that this environment and its influencing factors are much different and more complex than before and are characterised by reliance on information technology, new production technologies and methods and customer power, all of which are associated with market dynamics and complexity (Hakkak \& Ghodsi, 2015). In this environment, entrepreneurship can act as an effective agent of economic growth and increased competitiveness and job creativity (Thurik \& Wennekers, 2004). In areas where economic factors of business are inefficient, entrepreneurship can follow a destructive and unproductive path, because the direction of creativity depends on economic opportunities (Baumol, 1996). 
Human resources management: Human resource management is a term used to describe a wide variety of activities, including recruiting, retaining and nurturing talented and energetic workforce. It refers to the responsibility of managers to equip the organization with capable employees and ensure the suitability of their talents for their tasks. Some experts believe that if you hire the right people for every position in the business, the business is very likely to succeed (Ferris et al., 1998). Increasing environmental concerns and consequently the emergence of international environmental standards have forced organizations to adopt green strategies and incorporate green management measures in all organisational matters. In this regard, different human resources management units can play a very active role in the implementation of green human resource management measures by encouraging employees to pursue the goals of these measures through suitable and effective activities (Paillé, Chen, Boiral \& Jin, 2014).

\section{Methodology}

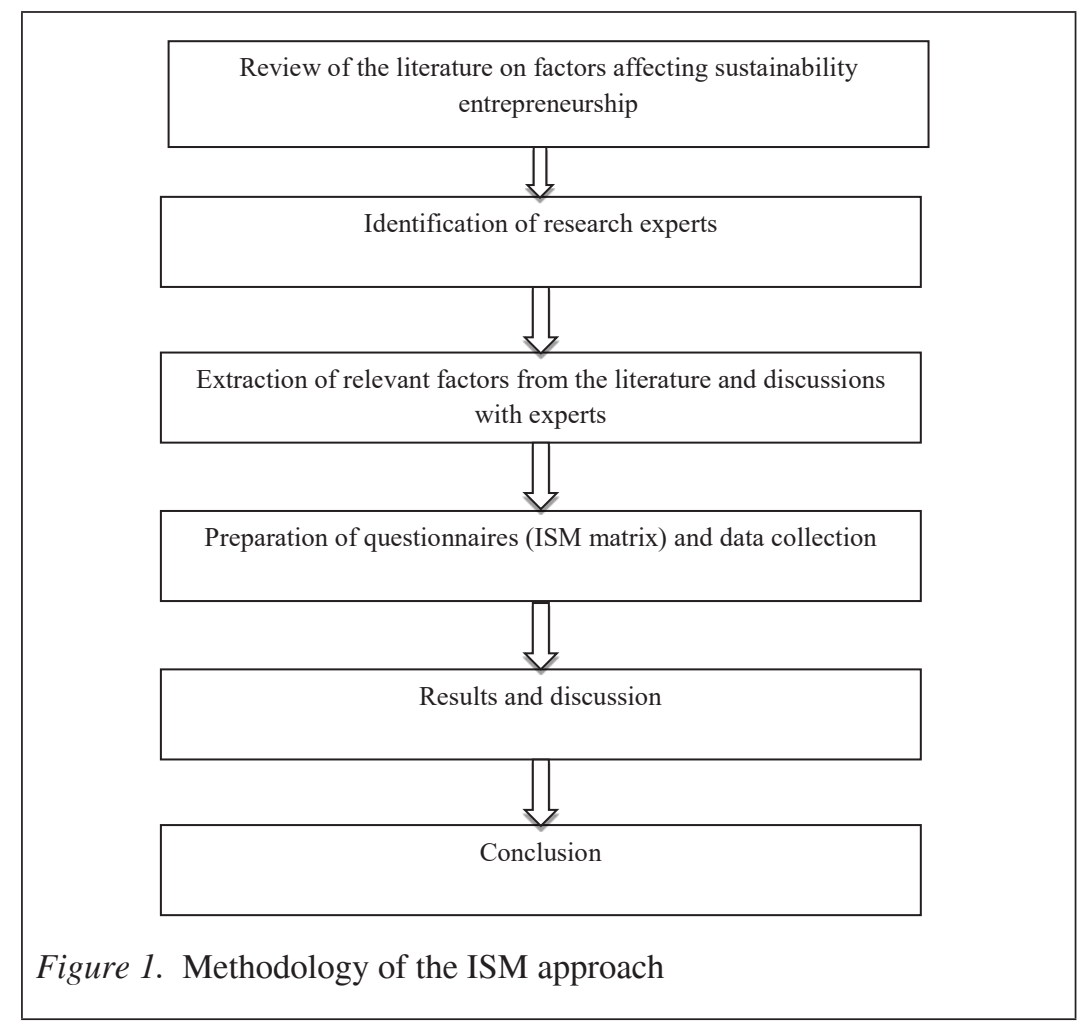


In the present study, research objectives are pursued by Interpretive Structural Modeling $(\mathrm{ISM})^{1}$. ISM has been developed as a tool for understanding complex situations. The research procedure followed in this study is illustrated in Figure 1. The method and results are discussed in the following sections.

\section{Interpretive Structural Modeling (ISM)}

ISM is an interactive learning process which can also be described as a method of system design, especially for economic and social systems. This method involves structuring a set of related elements into a comprehensive systematic model (Shahabadkar, 2012). The main idea of ISM is to draw on the expertise and experience of experts to break down a complex system into multiple subsystems (elements) and build a multi-level structural model (Mathiyazhagan, Govindan, NoorulHaq \& Geng, 2013). ISM helps us find order and direction for the complex relationships between elements of a system (Warfield, 1976). Many studies have used ISM to analyse the complex relationships between different phenomena. For example, ISM has been used to model marketing communication strategies for the acceptance of sustainability (Kannan, Pokharel, \& Kumar, 2009) to model the critical factors for integrating sustainability with innovation in SMEs (Yu et al., 2016) and to model sustainability factors in market-based firms (Agrawal, Kumar, \& Rahman, 2017). The methodology of ISM consists of the following steps (Jia, Diabat, \& Mathiyazhagan, 2015).

ISM Step 1 : Factors (criteria) considered for the system under consideration are listed.

ISM Step 2 : From the factors identified in step1, a contextual relationship is established among the factors to identify which pairs of factors should be examined.

ISM Step 3 : A structural self-interaction matrix (SSIM) is developed for factors, indicating pair-wise relationships among the factors of the system under consideration.

ISM Step 4 : A reachability matrix is developed from SSIM and the matrix is checked for transitivity. The transitivity of contextual relations is a basic assumption in ISM. It states that if variable $\mathrm{A}$ is related to $\mathrm{B}$ and $\mathrm{B}$ to $\mathrm{C}$, then $\mathrm{A}$ is necessarily related to $\mathrm{C}$.

ISM Step 5 : The reachability matrix obtained in step 4 is partitioned into different levels. 


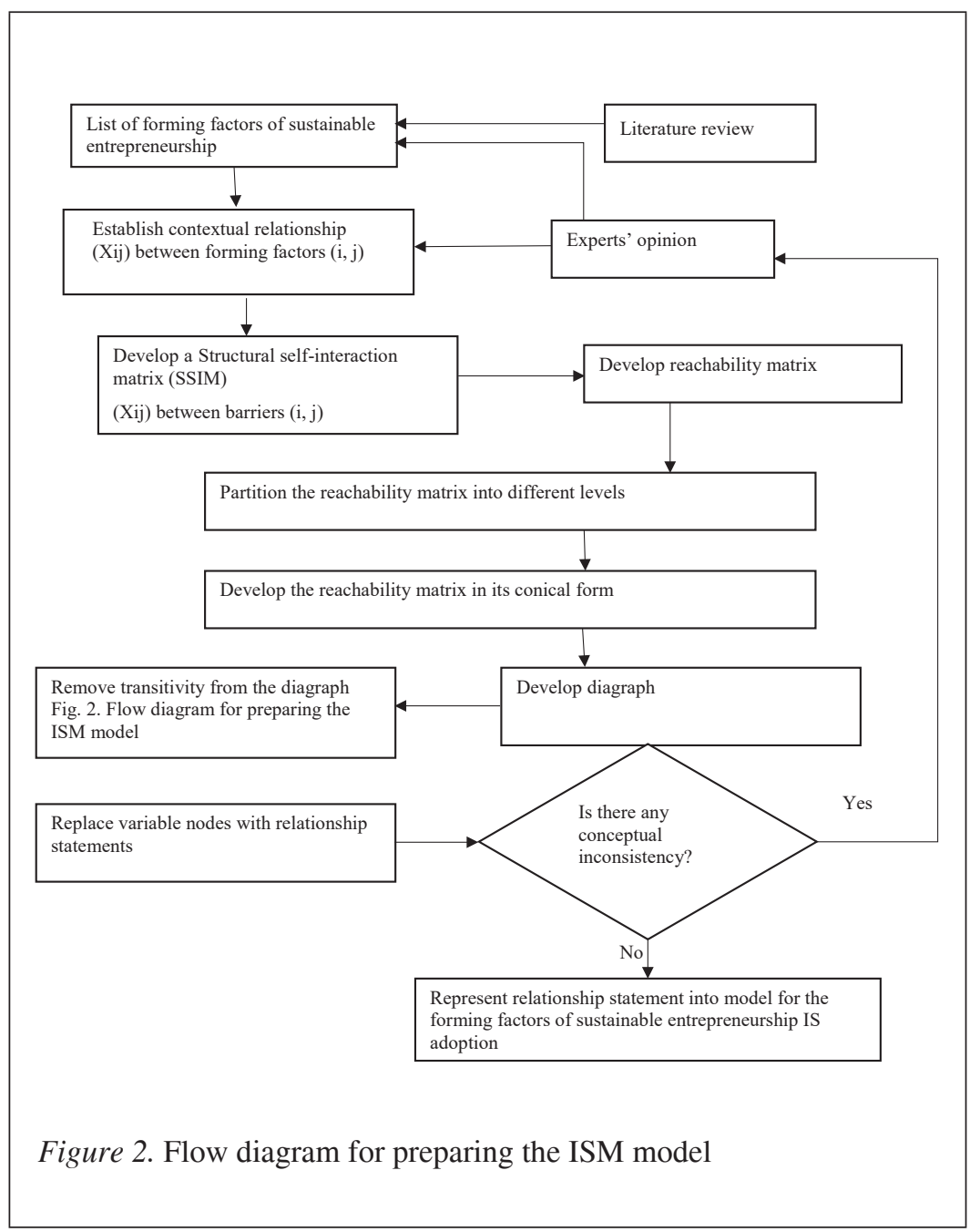

\section{Development of the Questionnaire}

To analyse the factors affecting sustainable entrepreneurship, eleven factors were extracted from the research literature. Based on previous studies, the independent initial model was developed in three dimensions: social, environmental and economic. The relevant factors and indicators were rganized into a list and provided to the experts who were selected by the snowball sampling method. The experts reviewed the list and verified the factors included. The validity of the questionnaire was evaluated by the 
Content Validity Index (CVI) of Walter and Basel. The factors that failed to obtain the minimum acceptable CVI $(0.79 \%)$, namely the "belief in the role of informal institutions in economic development", "elimination of market deficiencies", "regional distribution of employment opportunities" and "facilitating access to goods and services" were remove or modified. In the end, the validity of the entire questionnaire was calculated to 85 percent. Also, the experts suggested adding three other components to the list: "development of environmental annexes for programs and projects, "observing other environmental requirements of official authorities" and "attention to psychological needs in addition to material needs". The ultimate list of factors is presented in Table 1.

Table 1

Factors Included in the ISM Model of Sustainable Entrepreneurship

\begin{tabular}{|c|c|c|c|}
\hline Dimension & Factor & Items & References \\
\hline \multirow{7}{*}{$\begin{array}{l}\text { Environmental } \\
\text { dimension }\end{array}$} & \multirow[t]{4}{*}{ Resource preservation } & $\begin{array}{l}\text { Conservation of } \\
\text { resources (water, } \\
\text { energy, air, } \\
\text { minerals) }\end{array}$ & $\begin{array}{l}\text { (Hall, Daneke, \& } \\
\text { Lenox, 2010) (Dean } \\
\text { \& McMullen, 2007) } \\
\text { (Cohen \& Winn, 2007) } \\
\text { (Shepherd \& Patzelt, } \\
\text { 2011). }\end{array}$ \\
\hline & & $\begin{array}{l}\text { Strengthening } \\
\text { biodiversity }\end{array}$ & (Näyhä \& Horn, 2012) \\
\hline & & $\begin{array}{l}\text { Improving } \\
\text { ecosystems }\end{array}$ & $\begin{array}{l}\text { (Denny \& Marquart- } \\
\text { Pyatt, 2018)(Zedler \& } \\
\text { Kercher, 2005) (Shepherd } \\
\text { \& Patzelt, 2011) }\end{array}$ \\
\hline & & $\begin{array}{l}\text { Expansion of forests } \\
\text { and green spaces }\end{array}$ & $\begin{array}{l}\text { (Denny \& Marquart- } \\
\text { Pyatt, 2018) (Dean \& } \\
\text { McMullen, 2007) (Cohen } \\
\text { \& Winn, 2007). }\end{array}$ \\
\hline & \multirow[t]{3}{*}{ Green management } & $\begin{array}{l}\text { Waste reduction } \\
\text { planning }\end{array}$ & $\begin{array}{l}\text { (Hall, Daneke, \& Lenox, } \\
\text { 2010) (Clelland, Dean, \& } \\
\text { Douglas, 2000) }\end{array}$ \\
\hline & & $\begin{array}{l}\text { Planning and } \\
\text { management of } \\
\text { environmental } \\
\text { strategies }\end{array}$ & (Punnoose, 2009). \\
\hline & & $\begin{array}{l}\text { Setting up accurate } \\
\text { and purposeful } \\
\text { inspections }\end{array}$ & $\begin{array}{l}\text { (Wiesner, Chadee, \& } \\
\text { Best, 2018) }\end{array}$ \\
\hline
\end{tabular}


Malaysian Management Journal Vol. 24, July 2020 103-143

\begin{tabular}{|c|c|c|c|}
\hline Dimension & Factor & Items & References \\
\hline & & $\begin{array}{l}\text { Recycling and } \\
\text { recovery of waste }\end{array}$ & (Zeiss, 2018). \\
\hline & & $\begin{array}{l}\text { Operation } \\
\text { re-design and } \\
\text { management based } \\
\text { on environmental } \\
\text { requirements }\end{array}$ & $\begin{array}{l}\text { (Shove, 2003) } \\
\text { (Schaltegger \& Wagner, } \\
\text { 2011). }\end{array}$ \\
\hline & & $\begin{array}{l}\text { Conversion to } \\
\text { organic products }\end{array}$ & $\begin{array}{l}\text { (Muñoz, Janssen, } \\
\text { Nicolopoulou, \& } \\
\text { Hockerts, 2018) } \\
\text { (Shepherd \& Patzelt, } \\
\text { 2011). }\end{array}$ \\
\hline & & $\begin{array}{l}\text { Minimisation of } \\
\text { the adverse effects } \\
\text { of technology } \\
\text { development }\end{array}$ & $\begin{array}{l}\text { (Dong \& Hauschild, } \\
\text { 2017). }\end{array}$ \\
\hline & & $\begin{array}{l}\text { Utilization of green } \\
\text { technologies }\end{array}$ & $\begin{array}{l}\text { (Nacu \& Avasilcăi, } \\
\text { 2014). }\end{array}$ \\
\hline & & $\begin{array}{l}\text { Alignment with } \\
\text { environmental } \\
\text { opportunities } \\
\text { and threats and } \\
\text { associated market } \\
\text { trends (e.g. } \\
\text { climate change, } \\
\text { technological } \\
\text { changes, and } \\
\text { changes in } \\
\text { social tastes, } \\
\text { demographics, and } \\
\text { competition) }\end{array}$ & (Pomerantz, 2015). \\
\hline & & $\begin{array}{l}\text { Development of } \\
\text { environmental } \\
\text { annexes for } \\
\text { programs and } \\
\text { projects }\end{array}$ & Research experts. \\
\hline & \multirow[t]{5}{*}{ Legal requirements } & $\begin{array}{l}\text { Compliance with } \\
\text { environmental } \\
\text { standards }\end{array}$ & (Punnoose, 2009). \\
\hline & & Product labeling & (Chavan, 2001). \\
\hline & & $\begin{array}{l}\text { Requiring resource } \\
\text { use permissions }\end{array}$ & (Thornbush, 2017). \\
\hline & & $\begin{array}{l}\text { Compliance with } \\
\text { other environmental } \\
\text { requirements of } \\
\text { official authorities }\end{array}$ & Research experts. \\
\hline & & Quality certification & $\begin{array}{l}\text { (Haigh \& Hoffman, } \\
\text { 2014). }\end{array}$ \\
\hline
\end{tabular}

(continued) 
Malaysian Management Journal Vol. 24, July 2020 103-143

\begin{tabular}{|c|c|c|c|}
\hline Dimension & Factor & Items & References \\
\hline \multirow{17}{*}{$\begin{array}{l}\text { Economic } \\
\text { dimension }\end{array}$} & \multirow[t]{4}{*}{ Ecomonic benefits } & Profitability & (Certo \& Miller, 2008). \\
\hline & & Sales promotion & (Savitz \& Weber, 2006). \\
\hline & & Increase in ROI & (Kaplan \& Norton, 1996). \\
\hline & & Risk management & $\begin{array}{l}\text { (Schaltegger, Lüdeke- } \\
\text { Freund, \& Hansen, } \\
\text { 2012). }\end{array}$ \\
\hline & \multirow[t]{5}{*}{$\begin{array}{l}\text { Customers and } \\
\text { stakeholders }\end{array}$} & $\begin{array}{l}\text { Customer } \\
\text { relationship } \\
\text { management }\end{array}$ & (Vegholm, 2011). \\
\hline & & $\begin{array}{l}\text { Market share } \\
\text { preservation and } \\
\text { expansion }\end{array}$ & (Kaplan \& Norton, 1996). \\
\hline & & $\begin{array}{l}\text { Improvement of } \\
\text { relationships with } \\
\text { suppliers }\end{array}$ & (Kaplan \& Norton, 1996). \\
\hline & & $\begin{array}{l}\text { Relations with } \\
\text { legislators and } \\
\text { associations }\end{array}$ & (Kaplan \& Norton, 1996). \\
\hline & & Reputation & (Kaplan \& Norton, 1996). \\
\hline & \multirow[t]{3}{*}{$\begin{array}{l}\text { Human resources } \\
\text { management }\end{array}$} & $\begin{array}{l}\text { Human resources } \\
\text { recruitment }\end{array}$ & $\begin{array}{l}\text { (Figge, Hahn, } \\
\text { Schaltegger, \& Wagner, } \\
\text { 2002). }\end{array}$ \\
\hline & & $\begin{array}{l}\text { Human resources } \\
\text { maintenance }\end{array}$ & $\begin{array}{l}\text { (Roy, Boiral, \& Paillé, } \\
\text { 2013). }\end{array}$ \\
\hline & & $\begin{array}{l}\text { Training and } \\
\text { human resources } \\
\text { development }\end{array}$ & $\begin{array}{l}\text { (Park, Tahara, Jeong, \& } \\
\text { Lee, 2006). }\end{array}$ \\
\hline & \multirow[t]{5}{*}{$\begin{array}{l}\text { Efficient and effective } \\
\text { processes }\end{array}$} & Quality & $\begin{array}{l}\text { (Shepherd \& Patzelt, } \\
\text { 2011). }\end{array}$ \\
\hline & & $\begin{array}{l}\text { Reduction of } \\
\text { production time and } \\
\text { cost }\end{array}$ & $\begin{array}{l}\text { (Schaltegger \& Wagner, } \\
\text { 2011). }\end{array}$ \\
\hline & & $\begin{array}{l}\text { Innovation and } \\
\text { flexibility }\end{array}$ & (Schaper, 2002). \\
\hline & & $\begin{array}{l}\text { Creation and } \\
\text { exploitation } \\
\text { of competitive } \\
\text { advantage }\end{array}$ & $\begin{array}{l}\text { (Schaltegger, Lüdeke- } \\
\text { Freund, \& Hansen, } \\
\text { 2012). }\end{array}$ \\
\hline & & $\begin{array}{l}\text { Product development } \\
\text { through R\&D } \\
\text { processes }\end{array}$ & (Kaplan \& Norton, 1996). \\
\hline
\end{tabular}

(continued) 
Malaysian Management Journal Vol. 24, July 2020 103-143

\begin{tabular}{|c|c|c|c|}
\hline Dimension & Factor & Items & References \\
\hline & Culture building & $\begin{array}{l}\text { Strengthening of } \\
\text { cultural and social } \\
\text { values and norms } \\
\text { such as honesty, } \\
\text { trust ... }\end{array}$ & $\begin{array}{l}\text { (Swanson \& DeVereaux, } \\
\text { 2017) } \\
\text { (Schönborn et al., 2019). }\end{array}$ \\
\hline & & $\begin{array}{l}\text { Promotion of } \\
\text { citizenship } \\
\text { awareness and } \\
\text { knowledge (human } \\
\text { capital) }\end{array}$ & (Cohen \& Winn, 2007). \\
\hline & & $\begin{array}{l}\text { Promotion of human } \\
\text { rights and dignity }\end{array}$ & (Savitz, 2013) \\
\hline & & $\begin{array}{l}\text { Facilitation of } \\
\text { knowledge transfer } \\
\text { and learning from } \\
\text { experiences }\end{array}$ & $\begin{array}{l}\text { (Swanson \& DeVereaux, } \\
\text { 2017). }\end{array}$ \\
\hline & & $\begin{array}{l}\text { Development of } \\
\text { market information } \\
\text { systems and } \\
\text { elimination } \\
\text { of customer } \\
\text { information } \\
\text { deficiencies }\end{array}$ & $\begin{array}{l}\text { (Cohen \& Winn, 2007). } \\
\text { (Dean \& McMullen, } \\
\text { 2007). }\end{array}$ \\
\hline & Justice & $\begin{array}{l}\text { Employment of } \\
\text { women, youth, } \\
\text { and disadvantaged } \\
\text { groups }\end{array}$ & (Isaak, 2016). \\
\hline \multirow[t]{5}{*}{$\begin{array}{l}\text { Sosial } \\
\text { dimension }\end{array}$} & & $\begin{array}{l}\text { Support for } \\
\text { vulnerable groups }\end{array}$ & $\begin{array}{l}\text { (Juliani, Silva, Cunha, } \\
\text { \& Benneworth, 2019) } \\
\text { (Rinkinen, Oikarinen, \& } \\
\text { Melkas, 2016). }\end{array}$ \\
\hline & & $\begin{array}{l}\text { Providing equal } \\
\text { opportunities for } \\
\text { development }\end{array}$ & $\begin{array}{l}\text { (Shane \& Venkataraman, } \\
\text { 2000). } \\
\text { (Schönborn et al., 2019). }\end{array}$ \\
\hline & & $\begin{array}{l}\text { Organizational } \\
\text { justice }\end{array}$ & $\begin{array}{l}\text { (Shane \& Venkataraman, } \\
\text { 2000). (Schönborn et al., } \\
\text { 2019). }\end{array}$ \\
\hline & & $\begin{array}{l}\text { Strengthening fair } \\
\text { trade }\end{array}$ & (Cohen \& Winn, 2007). \\
\hline & & $\begin{array}{l}\text { Preservation of } \\
\text { resources and } \\
\text { opportunities for } \\
\text { future generations } \\
\text { (intergenerational } \\
\text { justice) }\end{array}$ & (Luo, 2007). \\
\hline
\end{tabular}


Malaysian Management Journal Vol. 24, July 2020 103-143

\begin{tabular}{|c|c|c|c|}
\hline Dimension & Factor & Items & References \\
\hline & \multirow[t]{6}{*}{ Social participation } & $\begin{array}{l}\text { Preparation for } \\
\text { or facilitation of } \\
\text { business partnerships }\end{array}$ & $\begin{array}{l}\text { (Dean \& McMullen, } \\
\text { 2007). }\end{array}$ \\
\hline & & $\begin{array}{l}\text { Establishment of } \\
\text { formal and informal } \\
\text { networks of } \\
\text { customers, suppliers, } \\
\text { and other actors } \\
\text { (NGOs) }\end{array}$ & $\begin{array}{l}\text { (Moore, Eng, \& Daniel, } \\
\text { 2003). }\end{array}$ \\
\hline & & $\begin{array}{l}\text { Strengthening } \\
\text { democracy and } \\
\text { freedom of choice }\end{array}$ & (Schönborn et al., 2019). \\
\hline & & $\begin{array}{l}\text { Increased attention } \\
\text { to group work } \\
\text { and collective } \\
\text { interest (enhancing } \\
\text { teamwork) }\end{array}$ & $\begin{array}{l}\text { (Bonnet, Quist, } \\
\text { Hoogwater, Spaans, \& } \\
\text { Wehrmann, 2006). }\end{array}$ \\
\hline & & $\begin{array}{l}\text { Development } \\
\text { of information } \\
\text { networks }\end{array}$ & (Cohen \& Winn, 2007). \\
\hline & & $\begin{array}{l}\text { Support for } \\
\text { associations, unions, } \\
\text { and groups }\end{array}$ & $\begin{array}{l}\text { (Shepherd \& Patzelt, } \\
\text { 2011). }\end{array}$ \\
\hline & \multirow[t]{5}{*}{ Social well-being } & $\begin{array}{l}\text { Provision of } \\
\text { environmental/ } \\
\text { human health }\end{array}$ & $\begin{array}{l}\text { (Oyebanji, Liyanage, \& } \\
\text { Akintoye, 2017). }\end{array}$ \\
\hline & & $\begin{array}{l}\text { Attention to } \\
\text { psychological } \\
\text { needs in addition to } \\
\text { material needs }\end{array}$ & Research experts. \\
\hline & & $\begin{array}{l}\text { Strengthening the } \\
\text { security of citizens } \\
\text { and protecting } \\
\text { them against } \\
\text { environmental and } \\
\text { economic threats }\end{array}$ & $\begin{array}{l}\text { (Kirkwood \& Walton, } \\
\text { 2010). }\end{array}$ \\
\hline & & $\begin{array}{l}\text { Meeting the } \\
\text { neglected and non- } \\
\text { market needs of } \\
\text { society and citizens }\end{array}$ & $\begin{array}{l}\text { (Fischer, Mauer, \& } \\
\text { Brettel, 2018). }\end{array}$ \\
\hline & & $\begin{array}{l}\text { Facilitation of access } \\
\text { to domestic and } \\
\text { foreign markets }\end{array}$ & $\begin{array}{l}\text { (Hall, Daneke, \& Lenox, } \\
\text { 2010). }\end{array}$ \\
\hline
\end{tabular}




\section{Application of ISM}

\section{Data Collection}

The mechanism of ISM involves making use of expert opinions based on techniques such as brainstorming, nominal group technique and others to identify interactions and relationships between variables. The current research analysis unit is at the business level and the data respondents are entrepreneurship experts,cademic experts,the trustees and entrepreneurs. In this study, the underlying relationships between the factors that affect sustainable entrepreneurship were identified with the help of ten experts on the concepts of sustainability and entrepreneurship.

\section{Structural Self-Interaction Matrix (SSIM)}

Considering the contextual relationships of each variable, an investigation must be performed to determine whether there is a relationship between the two factors ( $i$ and $j$ ) and also their associated relationships. Here, the relationship between the two factors ( $i$ and $j$ ) are denoted by four parameters:

- $\quad$ V: Factor i will help achieve factor j;

- $\quad$ A: Factor $\mathrm{j}$ will help achieve factor $\mathrm{i}$;

- $\quad \mathrm{X}$ : Factors i and j will help achieve each other; and

- $\quad$ O: Factors $\mathrm{i}$ and $\mathrm{j}$ are unrelated.

This matrix is shown in Table (2).

Table 2

The Structural Self-Interaction Matrix

\begin{tabular}{lllllllllll}
\hline Factors & F11 & F10 & F9 & F8 & F7 & F6 & F5 & F4 & F3 & F2 \\
\hline F1 & V & V & V & V & V & V & V & V & V & V \\
F2 & O & A & X & V & A & A & A & V & A & \\
F3 & V & X & V & V & X & X & X & V & & \\
F4 & A & A & A & X & A & A & A & & & \\
F5 & V & O & V & V & X & X & & & & \\
F6 & V & X & V & V & X & & & & & \\
F7 & V & X & V & V & & & & & & \\
F8 & A & A & A & & & & & & & \\
F9 & & & & & & & & & & \\
F10 & X & A & & & & & & & & \\
F11 & V & & & & & & & & & \\
\hline
\end{tabular}




\section{Initial Reachability Matrix}

At this stage, the reachability matrix must be derived from SSIM. This step involves reformatting SSIM into an initial reachability matrix. This reformatting is initialised by converting the information of each cell of SSIM into a binary digit (one/zero) according to the following rules:

A) If the cell $(i, j)$ of SSIM holds V, place 1 in the cell $(i, j)$ and 0 in the cell $(j, i)$ of the reachability matrix.

B) If the cell $(i, j)$ of SSIM holds A, place 0 in the cell $(i, j)$ and 1 in the cell $(j, i)$ of the reachability matrix.

C) If the cell $(i, j)$ of SSIM holds X, place 1 in both $(i, j)$ and $(j, i)$ cells of the reachability matrix.

D) If the cell $(i, j)$ of SSIM holds $O$, place 0 in both $(i, j)$ and $(j, i)$ cells of the reachability matrix. The initial reachability matrix developed according to these rules is provided in Table 3.

Table 3

The Initial Reachability Matrix

\begin{tabular}{cccccccccccc}
\hline Factors & F1 & F2 & F3 & F4 & F5 & F6 & F7 & F8 & F9 & F10 & F11 \\
\hline F1 & 1 & 1 & 1 & 1 & 1 & 1 & 1 & 1 & 1 & 1 & 1 \\
F2 & 0 & 1 & 0 & 1 & 0 & 0 & 0 & 1 & 1 & 0 & 0 \\
F3 & 0 & 1 & 1 & 1 & 1 & 1 & 1 & 1 & 1 & 1 & 1 \\
F4 & 0 & 0 & 0 & 1 & 0 & 0 & 0 & 1 & 0 & 0 & 0 \\
F5 & 0 & 1 & 1 & 1 & 1 & 1 & 1 & 1 & 1 & 0 & 1 \\
F6 & 0 & 1 & 1 & 1 & 1 & 1 & 1 & 1 & 1 & 1 & 1 \\
F7 & 0 & 1 & 1 & 1 & 1 & 1 & 1 & 1 & 1 & 1 & 1 \\
F8 & 0 & 0 & 0 & 1 & 0 & 0 & 0 & 1 & 0 & 0 & 0 \\
F9 & 0 & 1 & 0 & 1 & 0 & 0 & 0 & 1 & 1 & 0 & 1 \\
F10 & 0 & 1 & 1 & 1 & 0 & 1 & 1 & 1 & 1 & 1 & 1 \\
F11 & 0 & 0 & 0 & 1 & 0 & 0 & 0 & 1 & 1 & 0 & 1 \\
\hline
\end{tabular}

The final reachability matrix for the considered factors is presented in Table 4. This matrix was obtained by applying the transitivity property to the relationships of variables in the initial reachability matrix. The final reachability matrix is a square matrix where $r_{i j}=1$ if the element $r_{i}$ is reachable from element $r_{j}$, and is 0 otherwise. 
Table 4

Final Reachability Matrix

\begin{tabular}{cccccccccccc}
\hline Factors & F1 & F2 & F3 & F4 & F5 & F6 & F7 & F8 & F9 & F10 & F11 \\
\hline F1 & 1 & 1 & 1 & 1 & 1 & 1 & 1 & 1 & 1 & 1 & 1 \\
F2 & 0 & 1 & 0 & 1 & 0 & 0 & 0 & 1 & 1 & 0 & 1 \\
F3 & 0 & 1 & 1 & 1 & 1 & 1 & 1 & 1 & 1 & 1 & 1 \\
F4 & 0 & 0 & 0 & 1 & 0 & 0 & 0 & 1 & 0 & 0 & 0 \\
F5 & 0 & 1 & 1 & 1 & 1 & 1 & 1 & 1 & 1 & 1 & 1 \\
F6 & 0 & 1 & 1 & 1 & 1 & 1 & 1 & 1 & 1 & 1 & 1 \\
F7 & 0 & 1 & 1 & 1 & 1 & 1 & 1 & 1 & 1 & 1 & 1 \\
F8 & 0 & 0 & 0 & 1 & 0 & 0 & 0 & 1 & 0 & 0 & 0 \\
F19 & 0 & 1 & 0 & 1 & 0 & 0 & 0 & 1 & 1 & 0 & 1 \\
F10 & 0 & 1 & 1 & 1 & 1 & 1 & 1 & 1 & 1 & 1 & 1 \\
F11 & 0 & 1 & 0 & 1 & 0 & 0 & 0 & 1 & 1 & 0 & 1 \\
\hline
\end{tabular}

\section{Level Partitions}

Table 5

\section{Level Partition}

\begin{tabular}{ccccc}
\hline Factors & Reachability set & Antecedent set & Intersection set & Level \\
\hline F4 & 4,8 & 1234567891011 & 48 & I \\
F8 & 4,8 & 1234567891011 & 48 & I \\
F2 & 248911 & 12356791011 & 2911 & II \\
F9 & 248911 & 12356791011 & 2911 & II \\
F11 & 248911 & 12356791011 & 2911 & II \\
F3 & 234567891011 & 1356710 & 356710 & III \\
F5 & 234567891011 & 1356710 & 356710 & III \\
F6 & 234567891011 & 1356710 & 356710 & III \\
F7 & 234567891011 & 1356710 & 356710 & III \\
F10 & 234567891011 & 1356710 & 356710 & III \\
F1 & 1234567891011 & 1 & 1 & IV \\
\hline
\end{tabular}

The reachability and antecedent set for each barrier are obtained from the final reachability matrix (Warfield, 1974). The reachability set for a particular variable consists of the variable itself and the other variables which it may 
help achieve. The antecedent set consists of the variable itself and the other variables which may help achieve it. Then, the intersection of these sets is derived for all variables. The variable for which the reachability and the intersection sets are the same is given the top-level variable in the ISM hierarchy, one which would not help achieve any other variable above their own level. After the top-level element has been identified, it is discarded from the other remaining variables. Table 5 presents the 11 forming factors of sustainable entrepreneurship, together with reachability and antecedent set collections, the intersection set, and the level partitions.

\section{Formation of ISM Based Model}

From the final reachability matrix, the structural model is generated and is given in Figure 3. The relationship between the factors $j$ and $i$ is shown by an arrow pointing from $i$ to $j$. The resulting graph is called a digraph. Removing the transitivities as described in the ISM methodology, the digraph is finally converted into the ISM model.

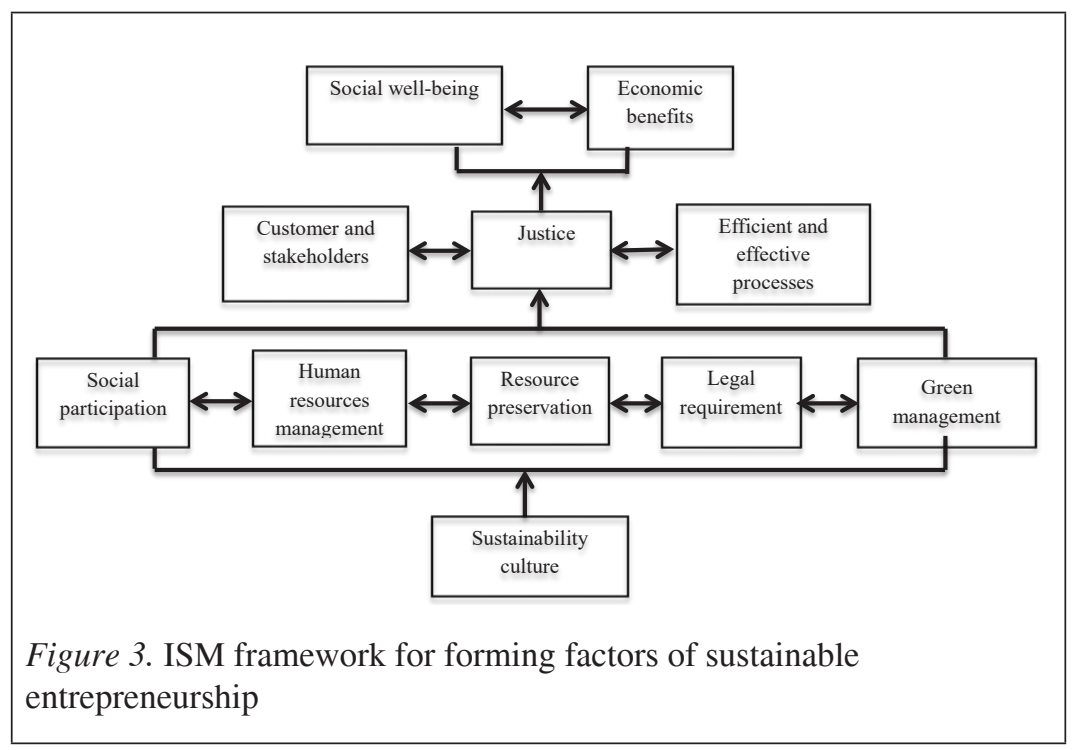

\section{MICMAC Analysis}

MICMAC is based on the multiplication properties of matrices (Jia, Diabat, \& Mathiyazhagan, 2015).

MICMAC is an abbreviation for 'Matrices Impacts' and 'CroisesMultipication Applique Classment' (Cross Impact Matrix Multiplication 
Applied to Classification). The purpose of MICMAC analysis is to analyse the drive power and dependence power of enablers. The analysis is done to identify the key enablers that drive the system in various categories. This categorisation is carried out according to the influence and power of dependence. The influence of power is the amount obtained by summing up the numbers in a row whereas the power of dependence is obtained by summing up of the numbers in column (Attri, Dev, \& Sharma, 2013). In fact, influence is indicative of the level of effectiveness of one factor on other factors and the power of dependence is interpreted as the level of receiving the impacts from other factors in one factor.

Based on their drive power and dependence power, the enablers in the present case study have been classified into four categories, as follows (Mathiyazhagan, Govindan, NoorulHaq \& Geng, 2013).

Autonomous Quadrant: This quadrant has weak driving power and weak dependence. Enablers in this quadrant are placed in Quadrant I. They are relatively disconnected from the system because they have few links. However, the links may be very strong. Dependent Quadrant: This category includes enablers which have weak driving power, but strong dependence power. They are placed in Quadrant-II. Linkage Quadrant: These have strong driving power and dependence power and are placed in Quadrant-III. They are unstable and so action on them will affect others and include a feedback effect on them. Independent Quadrant: These have strong driving power but weak dependence power. They are placed in Quadrant-IV. It is observed that a variable with a very strong driving power, called key variable, falls into the category of independent or linkage criteria.

The driver power and dependence power of each of these 11 factors in this case study are shown in Table 6. More details of the final full ISM model for the 11 factors are given in Figure 4.

As shown in Table 6 and Figure 4, the variables (justice, customers and stakeholder, efficient and effective processes, social well-being, economic benefits) are dependent variables which means rather than affecting sustainable entrepreneurship, they are affected by this variable. This effect is applied through independent variables (culture building, social participation, resource preservation, green management, legal requirements, human resource management), which are the basic foundations and main drivers of sustainable entrepreneurship. 
Malaysian Management Journal Vol. 24, July 2020 103-143

Table 6

Dependence Power and Driving Power

\begin{tabular}{ccccccccccccc}
\hline Factors & F1 & F2 & F3 & F4 & F5 & F6 & F7 & F8 & F9 & F10 & F11 & $\begin{array}{c}\text { Driving } \\
\text { power }\end{array}$ \\
\hline F1 & 1 & 1 & 1 & 1 & 1 & 1 & 1 & 1 & 1 & 1 & 1 & 11 \\
F2 & 0 & 1 & 0 & 1 & 0 & 0 & 0 & 1 & 1 & 0 & 1 & 5 \\
F3 & 0 & 1 & 1 & 1 & 1 & 1 & 1 & 1 & 1 & 1 & 1 & 10 \\
F4 & 0 & 0 & 0 & 1 & 0 & 0 & 0 & 1 & 0 & 0 & 0 & 2 \\
F5 & 0 & 1 & 1 & 1 & 1 & 1 & 1 & 1 & 1 & 1 & 1 & 10 \\
F6 & 0 & 1 & 1 & 1 & 1 & 1 & 1 & 1 & 1 & 1 & 1 & 10 \\
F7 & 0 & 1 & 1 & 1 & 1 & 1 & 1 & 1 & 1 & 1 & 1 & 10 \\
F8 & 0 & 0 & 0 & 1 & 0 & 0 & 0 & 1 & 0 & 0 & 0 & 2 \\
F9 & 0 & 1 & 0 & 1 & 0 & 0 & 0 & 1 & 1 & 0 & 1 & 5 \\
F10 & 0 & 1 & 1 & 1 & 1 & 1 & 1 & 1 & 1 & 1 & 1 & 10 \\
F11 & 0 & 1 & 0 & 1 & 0 & 0 & 0 & 1 & 1 & 0 & 1 & 5 \\
Dependence & 1 & 9 & 6 & 11 & 6 & 6 & 6 & 11 & 9 & 6 & 9 & \\
power & & & & & & & & & & & & \\
\hline
\end{tabular}

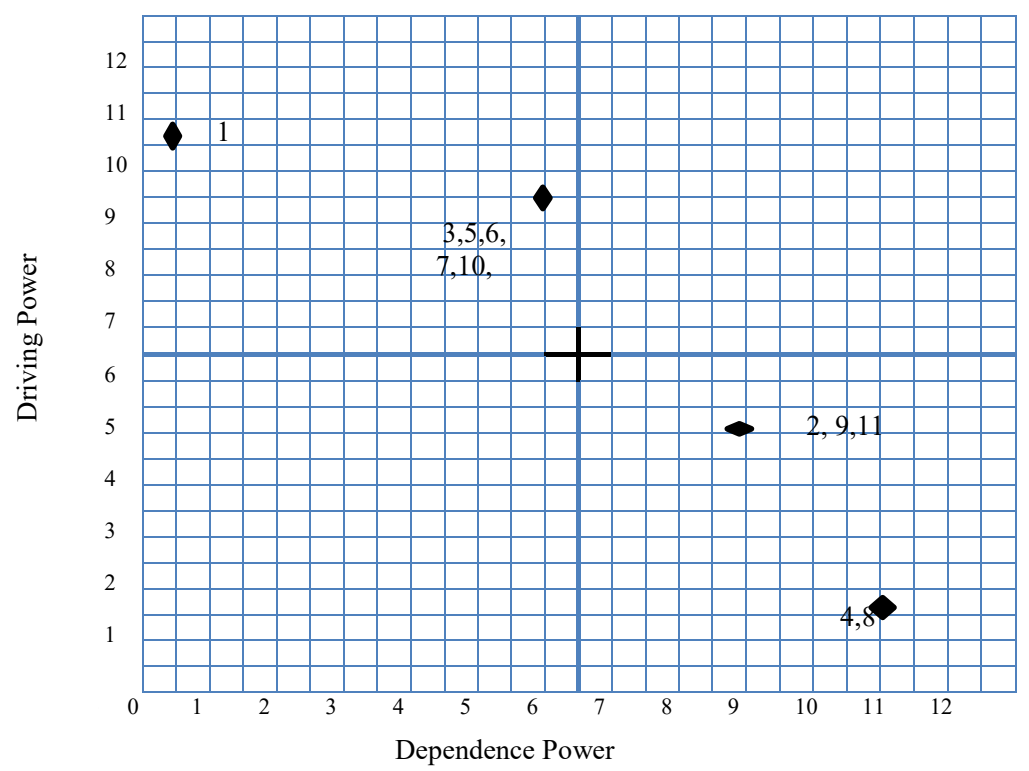

Figure 4. Driving power and dependence power 


\section{Discussion}

The results of the study revealed that the cultural dimension is positioned at the most fundamental level of sustainable entrepreneurship model. Theoretical foundations also suggest that culture has a profound impact on the evolution of an entrepreneurial ecosystem. Some researchers regard culture as the social aspect that constitutes the basis of a well-developed society (Margalit \& Halbertal, 1994). Culture is also considered a vital factor for sustainable development (Neck, Meyer, Cohen \& Corbett, 2004). In general, culture encompasses natural outlooks and common interests and knowledge of a people and the collective spirit of a society, and as such, can be considered among the most important elements of sustainable entrepreneurship. The promotion of a culture in a society facilitates the transfer of knowledge and experience and the acceptance of values among members of that society (Cohen, 2006). Promotion of social culture is a powerful impetus for achieving social, economic and environmental sustainability and ultimately business sustainability. Further, some scholars regard culture as the fourth pillar of sustainable development (Hawkes, 2001). This study found that cultural development plays a role in the environmental sustainability of businesses (compliance with legal requirements and principles of green management and resource preservation). This finding is consistent with the findings of (Schneider, Brief \& Guzzo, 1996).

Among the considered factors, those directly influenced by culture were green management, human resource management, social participation, legal requirements and resource preservation are reinforced. According to research findings, culture has an impact on all components of the environmental dimension. Adoption of environmental policies in the activities and operations of a business are carried out either voluntarily or compulsorily (through legal requirements), both of which are influenced by the culture of society. In addition to the environmental legal requirements, the environmental policies within the organisation are also influenced by the underlying culture of the society and the organisation. A culture of sustainability in which undertaking of environmental activities is considered a virtue affects the mission of the organisation by creating explicit values and beliefs in this regard.

Culture must deliver the empowerment necessary for individuals, groups and institutions to partake in the development process and achieve sustainable development objectives and this cannot be done without social participation. According to (Stuber, 2009), social participation is an important factor of sustainability in business and gives individuals and employees the 
opportunity to expand resources and components of cultural development. Stuber attributes the failure of some businesses in the area of sustainability to the absence of stakeholders in social participation. Some researchers believe that social participation is a pillar of sustainability.

Although previous studies and theories have not explored the effects of cultural development on human resource management systems, some researchers have stated that personnel and human resources can greatly contribute to sustainable development through cooperation and teamwork in efforts toward sustainability goals (Shepherd \& Patzelt, 2011). Another component placed in the third level of the developed model is legal requirements. Legal requirements are aligned with and influenced by the cultural values of the society and are designed to address its environmental and social needs. According to (Russo \& Fouts, 1997), legal requirements improve the capabilities, integrity, and dynamism of businesses. Some scholars believe that with the facilitation of collaboration and communication, people show support for environmental legal requirements and participation in setting environmental strategies in order to gain competitive advantage ( $\mathrm{Li}$, Zhao, Zhang, Chen, \& Cao, 2018).

Positioned in the second level of the sustainable entrepreneurship model are customer-centricity, efficient and effective processes, and justice, which are the immediate results of focus on the functional components of sustainable entrepreneurship at the second level and explain how the final results are achieved at the fourth level. With the intense competition in markets and extensive developments in the area of business management, customers and stakeholders have become the focus of entrepreneurship (Vegholm, 2011). Some researchers have emphasized that communicating with customers and stakeholders and addressing their demands and maintaining and creating value for customers and stakeholders are of particular importance for creating a sustainable business and are likely to result in increased revenue generation (Rozek \& Karlicek, 2014). The results of this study also suggest that attention to the sustainability values and requirements such as green management measures, resource preservation, compliance with legal requirements and human resource management are in line with and representative of customercentricity of businesses.

Alongside customer-centricity, the second level has labeled justice as an outcome of entrepreneurial sustainability. According to the theoretical foundations, justice is a basic principle of a healthy society, in which all social, economic, environmental and cultural factors contribute to its stability and flexibility, and today the promotion of justice is one of the key indicators of a healthy society. Sustainable development, which was once mostly defined 
by the environmental aspect of sustainability, now encompasses the concept of equitable and balanced development. Consistent with the findings of this study, researchers (Luo, 2007) believes that social justice is an important social structure that is inherently needed for sustainable entrepreneurship that preserves resources and opportunities for the next generation. According to Normann, Ellegaard and Møller (2017), social justice can be treated as a measure for assessing sustainability. Meanwhile, some scholars have identified justice as the central value of sustainable development (Shepherd $\&$ Patzelt, 2011). The last and most important factor at this level is the efficient and effective processes which indeed has the strongest relation with other factors of this level. Effective and efficient processes pave the way for social justice and attention to customers and stakeholders and provide infrastructure and opportunities to achieve economic, social, and environmental goals. According to Pinzone et al., (2018), human resources and all of the agents involved in business must get involved in learning and growth processes with the aims of improving performance, productivity and quality, creating innovation and also earning customer satisfaction which is vital for the success of the business.

Finally, at the first level, we have two factors, economic benefits and social well-being, as the ultimate outcomes of sustainable entrepreneurship. Social well-being has long been an issue of great concern to human societies and governments often try to provide the people with the best possible level of wellbeing through a fair distribution of services. According to the World Health Organisation (WHO), well-being is to enjoy a good level of physical, mental and social health. Cummins (2000) asserted that the social well-being is one of the key indicators of sustainable entrepreneurship and a global structure encompassing cultural and mental objectives (satisfaction) and the outcome of components such as material well-being, individual and environmental health, affection and security. However, Gallo and Matthews (2003) claimed that the social well-being is understood as one's understanding of his position in society, which can be a non-economic outcome of sustainability and further contributes to improving one's psychological needs. Alongside social well-being, this level contains the economic benefit component.

Although this study recognised the manifestation of sustainability values in social culture as the most fundamental underlying variable for sustainable entrepreneurship and found economic benefits and social well-being as the end result of this entrepreneurship, the model appears to be flowing in a cycle. Researchers have pointed to the role of economic factors in technological innovation and development by providing necessary resources to the entrepreneurial sector (Shumpeter, 1968). The well-being and security of an individual are associated with the well-being and security of his society, and 
the presence of social cohesion, sense of companionship and patience creates a condition in which people exhibit an increased sense of accountability. Like previous studies, this study found no clear distinction between many socio-economic indicators of sustainable development and reached the conclusion that non-economic components such as basic needs, education, health and others. should be incorporated in the economic evaluations. The economic benefits and social well-being constitute two main pillars of the developed sustainable entrepreneurship model, which means every business needs substantial financial resources to survive and thrive in the face of constant changes and competitive market conditions, but must also consider non-economic gains to meet the requirements of a sustainable business in all of its three dimensions. Here, social well-being, as a non-economic outcome of sustainable entrepreneurship, represents the environmental and social dimensions of sustainability.

\section{Conclusion}

This research has theoretical and practical implications for policymakers, entrepreneurs and people interested in undertaking entrepreneurial activities. Policymakers can play a role in promoting sustainability by raising attention to sustainability, culture building, supporting social partnerships and formulating legal requirements for business activities. Entrepreneurs and business owners can enhance the economic success of their business and also contribute to the well-being of their communities through attention to the dimensions of sustainability, especially when the public considered this attention a requirement for ethical business activity. Since market deficiencies and inefficiencies create many entrepreneurial opportunities, prospective entrepreneurs can take advantage of this situation by launching new businesses to compete with traditional businesses that suffer from these inefficiencies or new services to eliminate these issues for established businesses.

The cornerstone of sustainable entrepreneurship is the development of sustainable entrepreneurial values in the culture of society. Raising citizens' awareness and knowledge and reinforcing cultural and social values and norms around the needs of sustainable entrepreneurship are tremendous tasks that require consistent efforts from the government, business owners and prospective entrepreneurs. The sustainable entrepreneurship model developed in this study illuminates the expected outcomes of these efforts 
and provides a roadmap for achieving these objectives. The benchmark for evaluating the sustainability of entrepreneurship is the amount of attention paid by the business and its efforts and achievements in improving the status of these components and reaching the ultimate outcomes, which are the economic success and leaving a positive impact on social well-being. This model emphasises the need for businesses that accommodate the economic, mental and biological needs of society at the same time. It also suggests that the success of sustainable entrepreneurship must be measured not only in terms of financial success but also by success in promoting social well-being. The results also show that it is imperative to strengthen social values and norms in line with the requirements of environmental resource preservation and according to its social benefits, promote citizen awareness and knowledge about sustainable entrepreneurship and also frame sustainable entrepreneurship as being in the common interest of society, businesses and customers so as to encourage businesses to seriously consider the benefits of this type of entrepreneurship.

Considering the fundamental role of social culture in the development of sustainable entrepreneurship and guiding entrepreneurs towards sustainability, strengthening cultural and social values and norms regarding sustainability, promoting citizen awareness and knowledge about this issue, promoting human rights and dignity and the development of market information are highly recommended for the promotion of sustainable entrepreneurship. In other words, new businesses must be launched and supported to cover these issues. Also, since economic success and contribution to social well-being were recognised as the ultimate goals and outputs of sustainable entrepreneurship, the success of sustainable entrepreneurship must be measured by financial success as well as success in promoting social well-being. It is also recommended to reinforce social values and norms according to the requirements of environmental resource preservation and its social benefits, promote citizen awareness and knowledge about sustainable entrepreneurship and promote sustainable entrepreneurship as being in the common interest of society, businesses and customers so that prospective entrepreneurs show more interest in considering the benefits of this entrepreneurship. This model provides a roadmap for achieving sustainable entrepreneurship that can be used at the business level and at the policy level. Each business can determine and use criteria related to each of the dimensions and components according to its requirements.

\section{Endnotes}

$1 \quad$ Interpretative Structural Modeling 


\section{Acknowledgement}

This research received no specific grant from any funding agency.

\section{References}

Abdollahzadeh, G., \& Sharifzadeh, A. (2014). Rural residents' perceptions toward tourism development: A study from Iran. International Journal of Tourism Research, 16(2), 126-136.

Aboagye, S., (2017). Economic expansion and environmental sustainability nexus in Ghana. African Development Review, 29(2), 155-168.

Aboagye, S., \& Kwakwa, P. A. (2014). The relationship between economic growth and environmental sustainability: Evidence from selected Sub-Sahara African countries. Ghanaian Journal of Economics, 2(1), 135-153.

Agrawal, A. K., Kumar, D., \& Rahman, Z. (2017). An ISM approach for modelling the enablers of sustainability in market-oriented firms. International Journal of Business Excellence, 12(1), 23-45.

Ahi, P., \& Searcy, C. (2013). A comparative literature analysis of definitions for green and sustainable supply chain management. Journal of cleaner production, 52, 329-341.

Alavi, M., Kayworth, T. R., \& Leidner, D. E. (2005). An empirical examination of the influence of organizational culture on knowledge management practices. Journal of management information systems, 22(3), 191-224.

Alberti, F. G., \& Varon Garrido, M. A. (2017). Can profit and sustainability goals co-exist? New business models for hybrid firms. Journal of Business Strategy, 38(1), 3-13.

Alipour, A., Shaghagh, F., \& Barghi, I. Z. (2012). A differential distribution of entrepreneurial traits in left-and right-handed students. School Psychology Quarterly, 1(3), 63-81

Aras, G., \& Crowther, D. (2009). Corporate sustainability reporting: A study in disingenuity? Journal of Business Ethics, 87(1), 279.

Attri, R., Dev, N., \& Sharma, V. (2013). Interpretive structural modelling (ISM) approach: An overview. Research Journal of Management Sciences, 2319(2), 1171.

Baker, T., \& Nelson, R. E. (2005). Creating something from nothing: Resource construction through entrepreneurial bricolage. Administrative science quarterly, 50(3), 329-366.

Barthelme, L. C. (2017). Sustainable entrepreneurship in practice: Paving the way to a new sustainable society? https://core.ac.uk/display/87690965 
Baruah, B., \& Ward, A. (2015). Metamorphosis of intrapreneurship as an effective organizational strategy. International Entrepreneurship and Management Journal, 11(4), 811-822.

Baumol, W. J. (1996). Entrepreneurship: Productive, unproductive, and destructive. Journal of Business Venturing, 11(1), 3-22.

Bell, J., \& Stellingwerf, J. J. (2012). Sustainable entrepreneurship: The motivations and challenges of sustainable entrepreneurs in the renewable energy industry (Unpublished Master thesis). Jonkoping International Business Scholl, Jonkoping University.

Belz, F. M., \& Binder, J. K. (2017). Sustainable entrepreneurship: A convergent process model. Business Strategy and the Environment, 26(1), 1-17.

Bhar, C. (2017). Environmental Sustainability: The emerging issues in India's textile sector. International Journal of Social Ecology and Sustainable Development (IJSESD), 8(4), 48-60.

Brundtland, G. H. (1987). Report of the world commission on environment and development: Our common future. Retrieved from https://www. sc.com.my/

Bunch, R., Johnson, J., \& Robert, A. (2008). A closer look at applied sustainability centers. In: Aspen, CO: The Aspen Institute Center for Business Education.

Buysse, K., \& Verbeke, A. J. S. m. j. (2003). Proactive environmental strategies: A stakeholder management perspective. Strategic Management Journal, 4(5), 453-470. https://doi.org/10.1002/smj.299

Cai, S., Chen, X., \& Bose, I. (2013). Exploring the role of IT for environmental sustainability in China: An empirical analysis. International Journal of Production Economics, 146(2), 491-500.

Calabrese, A., Costa, R., Menichini, T., Rosati, F., \& Sanfelice, G. (2013). Turning corporate social responsibilityロdriven opportunities in competitive advantages: A twoØdimensional model. Knowledge and Process Management, 20(1), 50-58.

Carter. (2005). Constraints on women enterprise. 27th conference enterprise and small business. University of Strathclyed in Glasgow.

Chavan, R. (2001). Indian textile industry-environmental issues. Indian Journal of Fibre \& Textile Research, 26, 11-21.

Choi, D. Y., \& Gray, E. R. (2008). The venture development processes of "sustainable" entrepreneurs. Management Research News, 31(8), 558-569.

Cohen, B. (2006). Sustainable valley entrepreneurial ecosystems. Business strategy and the Environment, 15(1), 1-14.

Costanza, R., d'Arge, R., De Groot, R., Farber, S., Grasso, M., Hannon, B., Paruelo, J. (1997). The value of the world's ecosystem services and natural capital. Nature, 387(6630), 253. 
Cummins, R. A., (2000). Objective and subjective auality of life: An interactive model. Social Indicators Research, 52(1), 55-72.

Dean, T. J., \& McMullen, J. S. (2007). Toward a theory of sustainable entrepreneurship: Reducing environmental degradation through entrepreneurial action. Journal of Business Venturing, 22(1), 50-76.

Engert, S., \& Baumgartner, R. J. J. J. o. c. p. (2016). Corporate sustainability strategy-bridging the gap between formulation and implementation. Journal of Cleaner Production, 113, 822-834.

Epstein, M. J., \& Roy, M.-J. (2001). Sustainability in action: Identifying and measuring the key performance drivers. Long range planning, 34(5), 585-604.

Etzioni, O. (1996). Moving up the information food chain: Deploying softbots on the world wide web. Paper presented at the Proceedings of the national conference on artificial intelligence. Department of Computer Science and Engineering University of Washington https://www.aaai.org/Papers/AAAI/1996/AAAI96-196.pdf

Ferris, G. R., Arthur, M. M., Berkson, H. M., Kaplan, D. M., HarrellCook, G., \& Frink, D. D. (1998). Toward a social context theory of the human resource management-organization effectiveness relationship. Human Resource Management Review, 8(3), 235-264.

Figge, F., Hahn, T., Schaltegger, S., \& Wagner, M. (2002). The sustainability balanced scorecard-linking sustainability management to business strategy. Business Strategy and the Environment, 11(5), 269-284.

Finlay-Robinson, D. (2013). Change and opportunity: the role of leaders and SMEs in creating new business futures. Development and Learning in Organizations: An International Journal, 27(3), 5-7.

Fischer, D., Mauer, R., \& Brettel, M. (2018). Regulatory focus theory and sustainable entrepreneurship. International Journal of Entrepreneurial Behavior \& Research, 24(2), 408-428.

Fischler F. (2014) Sustainability: The concept for modern society. In Weidinger C., Fischler F., Schmidpeter R. (Eds), Sustainable Entrepreneurship. CSR, sustainability, ethics \& governance. Springer, Berlin, Heidelberg. https://doi.org/10.1007/978-3-642-38753-1_2

Gallo, L. C., \& Matthews, K. A. (2003). Understanding the association between socioeconomic status and physical health: Do negative emotions play a role? Psychological Bulletin, 129(1), 10.

García, M., Eizaguirre, S., \& Pradel, M. (2015). Social innovation and creativity in cities: A socially inclusive governance approach in two peripheral spaces of Barcelona. City, Culture and Society, 6(4), 93100. 
Gibb, A. (2005). Towards the entrepreneurial university: Entrepreneurship education as a lever for change. Policy paper. National Council for Graduate Entrepreneurship, Birmingham. http://www.ncge.org.uk

Gorman, A., \& Fischer, G. (2009). Toward an analytic framework for understanding and fostering peer-support communities in using and evolving software products. Paper presented at the Proceedings of the fourth international conference on Communities and Technologies.

Greco, A., \& De Jong, G. (2017). Sustainable entrepreneurship: Definitions, themes and research gaps. In: University of Groningen. Working Paper series. https://doi: 10.13140/RG.2.2.16751.12968

Gregory, D., Johnston, R., Pratt, G., Watts, M., \& Whatmore, S. (2011). The dictionary of human geography. John Wiley \& Sons.

Hakkak, M., \& Ghodsi, M. (2015). Development of a sustainable competitive advantage model based on balanced scorecard. International Journal of Asian Social Science, 5(5), 298-308.

Hall, J. K., Daneke, G. A., \& Lenox, M. J. (2010). Sustainable development and entrepreneurship: Past contributions and future directions. Journal of Business Venturing, 25(5), 439-448.

Hammel, J., Magasi, S., Heinemann, A., Whiteneck, G., Bogner, J., \& Rodriguez, E. (2008). What does participation mean? An insider perspective from people with disabilities. Disability and Rehabilitation, 30(19), 1445-1460.

Hawkes, J. (2001). The fourth pillar of sustainability: Culture's essential role in public planning: Common ground. Retrieved from https:// www.researchgate.net/publication/20002953

Hinrichsen, D. (1987). Our common future: A reader's guide. Earthscan.

Hockerts, K., \& Wüstenhagen, R. (2010). Greening Goliaths versus emerging Davids-Theorizing about the role of incumbents and new entrants in sustainable entrepreneurship. Journal of Business Venturing, 25(5), 481-492.

Hoffman, K. D., \& Ingram, T. N. (1992). Service provider job satisfaction and customer. Journal of Services Marketing, 6(2), 68-78.

Hopwood, B., Mellor, M., \& O’Brien, G. (2005). Sustainable development: Mapping different approaches. Sustainable Development, 13(1), 3852.

Huatuco, L. D. H., Montoya-Torres, J. R., Shaw, N., Calinescu, A., Okongwu, U., Morimoto, R., \& Lauras, M. (2013). The maturity of supply chain sustainability disclosure from a continuous improvement perspective. International Journal of Productivity and Performance Management. 62(8). https://doi.org/10.1108/IJPPM-07-2013-0131 
Hutchins, M. J., \& Sutherland, J. W. (2008). An exploration of measures of social sustainability and their application to supply chain decisions. Journal of cleaner production, 16(15), 1688-1698.

IPCC., A. (2007). Intergovernmental panel on climate change. Climate change 2007: Synthesis report. Retrieved from https://www.ipcc.ch/

Janušauskaitė, F. T., Nolan, B., \& Whelan, C. (2003). Monitoring quality of life in Europe. European Foundation for the Improvement of Living and Working Conditions. Luxemburg: Office for Official Publications of the European Communities.

Jia, P., Diabat, A., \& Mathiyazhagan, K. (2015). Analyzing the SSCM practices in the mining and mineral industry by ISM approach. Resources Policy, 46, 76-85.

Jia, P., Diabat, A., \& Mathiyazhagan, K. (2015). Analyzing the SSCM practices in the mining and mineral industry by ISM approach. Resources Policy, 46, 76-85.

Johnson, P. S., Parker, S. C., \& Wijbenga, F. (2006). Nascent entrepreneurship research: Achievements and opportunities. Small Business Economics, 27(1), 1-4.

Kannan, G., Pokharel, S., \& Kumar, P. S. (2009). A hybrid approach using ISM and fuzzy TOPSIS for the selection of reverse logistics provider. Resources, Conservation and Recycling, 54(1), 28-36.

Károly, K. (2011). Rise and fall of the concept sustainability. Journal of Environmental Sustainability, 1(1), 1.

Klewitz, J., \& Hansen, E. G. (2011). Sustainability-oriented innovation in SMEs: A systematic literature review of existing practices and actors involved. Journal of Cleaner Production, 65, 57-75.

Korten, D. C. (2010). Agenda for a new economy: From phantom wealth to real wealth. Berrett-Koehler Publishers.

Langstaff, K., \& Brzozowski, V. (2017). Managing environmental sustainability in a healthcare setting. Paper presented at the Healthcare management forum. https://doi.org/10.1177/0840470416675178

Lee, J. J., \& Hwang, J. (2016). An emotional labor perspective on the relationship between customer orientation and job satisfaction. International Journal of Hospitality Management, 54, 139-150.

Lee, L., Wong, P. K., Der Foo, M., \& Leung, A. (2011). Entrepreneurial intentions: The influence of organizational and individual factors. Journal of Business Venturing, 26(1), 124-136.

Lepage, A. (2009). The quality of life as attribute of sustainability. The TQM Journal, 21(2), 105-115.

Li, D., Zhao, Y., Zhang, L., Chen, X., \& Cao, C. (2018). Impact of quality management on green innovation. Journal of Cleaner Production, $170,462-470$. 
Lindholm Dahlstrand, Å., (2007). Technology-based entrepreneurship and regional development: The case of Sweden. European Business Review, 19(5), 373-386.

Luo, Y., (2007). A coopetition perspective of global competition. Journal of World Business, 42(2), 129-144.

Macke, J., Casagrande, R. M., Sarate, J. A. R., \& Silva, K. A. (2018). Smart city and quality of life: Citizens' perception in a Brazilian case study. Journal of Cleaner Production, 182, 717-726.

Margalit, A., \& Halbertal, M. (1994). Liberalism and the right to culture. In M. Meutner, A. Sagi and R. Shamir (Eds.), Multiculturalism in a Jewish democratic state (pp. 93-105). Tel Aviv: Ramot Publishing.

Margalit, A., \& Halbertal, M. (2004). Liberalism and the right to culture. Social Research: An International Quarterly, 71(3), 529-548.

Mathiyazhagan, K., Govindan, K., NoorulHaq, A., \& Geng, Y. (2013). An ISM approach for the barrier analysis in implementing green supply chain management. Journal of Cleaner Production, 47, 283-297.

McWilliams, A., \& Siegel, D. (2001). Corporate social responsibility: A theory of the firm perspective. Academy of Management Review, 26(1), 117-127.

Merritt, D. H., \& Snyder, S. M. (2014). Maltreatment type and behaviors: Does listening matter? Child abuse \& neglect. Journal Child Abuse and Neglect, 38(12), 2062-2071.

Milis, K., \& Mercken, R. (2004). The use of the balanced scorecard for the evaluation of information and communication technology projects. International Journal of Project Management, 22(2), 87-97.

Moore, J. L. (2004). Recreating the university from within: Sustainability and transformation in higher education. CITY?: University of British Columbia.

Muehlebach, A. (2001). "Making Place" at the United Nations: Indigenous cultural politics at the UN working group on indigenous populations. Cultural Anthropology, 16(3), 415-448.

Muñoz, P., \& Dimov, D. (2015). The call of the whole in understanding the development of sustainable ventures. Journal of Business Venturing, 30(4), 632-654.

Mupfasoni, B., Kessler, A., \& Lans, T. (2018). Sustainable agricultural entrepreneurship in Burundi: Drivers and outcomes. Journal of Small Business and Enterprise Development, 25(1), 64-80.

Nacu, C. M., \& Avasilcăi, S. (2014). Technological ecopreneurship: Conceptual approaches. Procedia-Social and Behavioral Sciences, 124, 229-235.

Nawaz, W., \& Koc, M. (2018). Development of a systematic framework for sustainability management of organizations. Journal of Cleaner Production, 171, 1255-1274. 
Neck, H. M., Meyer, G. D., Cohen, B., \& Corbett, A. C. (2004). An entrepreneurial system view of new venture creation. Journal of Small Business Management, 42(2), 190-208.

Neutzling, D. M., Land, A., Seuring, S., \& do Nascimento, L. F. M. (2018). Linking sustainability-oriented innovation to supply chain relationship integration. Journal of Cleaner Production, 172, 34483458.

Normann, U., Ellegaard, C., \& Møller, M. M. (2017). Supplier perceptions of distributive justice in sustainable apparel sourcing. International Journal of Physical Distribution \& Logistics Management, 47(5), 368-386.

Oyebanji, A. O., Liyanage, C., \& Akintoye, A. (2017). Critical Success Factors (CSFs) for achieving Sustainable Social Housing (SSH). International Journal of Sustainable Built Environment, 6(1), 216227.

Paillé, P., Chen, Y., Boiral, O., \& Jin, J. (2014). The impact of human resource management on environmental performance: An employeelevel study. Journal of Business Ethics, 121(3), 451-466.

Park, P.-J., Tahara, K., Jeong, I.-T., \& Lee, K.-M. (2006). Comparison of four methods for integrating environmental and economic aspects in the end-of-life stage of a washing machine. Resources, Conservation and Recycling, 48(1), 71-85.

Parris, T. M., \& Kates, R. W. (2003). Characterizing and measuring sustainable development. Annual Review of Environment and Resources, 28(1), 559-586.

Parrish, B. D. (2006). Beyond cleaner production: Entrepreneurship and the design of sustainable enterprise. Paper presented at the International Conference on Green and Sustainable Innovation.

Pinzone, M., Albè, F., Orlandelli, D., Barletta, I., Berlin, C., Johansson, B., \& Taisch, M. (2018). A framework for operative and social sustainability functionalities in Human-Centric Cyber-Physical Production Systems. Computers \& Industrial Engineering. 139, https://doi.org/10.1016/j.cie.2018.03.028

Pretty, J., Hine, R., \& Peacock, J. (2006). Green exercise: The benefits of activities in green places-Little has been said about the potential emotional or health benefits of the natural environment in arguments about conservation. Yet. Biologist-London, 53(3), 143-148.

Renard, M.-C. (2003). Fair trade: quality, market and conventions. Journal of Rural Studies, 19(1), 87-96.

Rotheroe, N., \& Richards, A. (2007). Social return on investment and social enterprise: Transparent accountability for sustainable development. Social Enterprise Journal, 3(1), 31-48. 
Rozek, J., \& Karlicek, M. (2014). Customer lifetime value as the $21 \mathrm{St}$ century marketing strategy approach. Central European Business Review, 3(2), 28-35.

Russo, M. V., \& Fouts, P. A. (1997). A resource-based perspective on corporate environmental performance and profitability. Academy of Management Journal, 40(3), 534-559.

Saarenketo, S., Puumalainen, K., Kuivalainen, O., \& Kyläheiko, K. (2009). A knowledge-based view of growth in new ventures. European Business Review, 21(6), 531-546.

Saunila, M., Nasiri, M., Ukko, J., \& Rantala, T. (2019). Smart technologies and corporate sustainability: The mediation effect of corporate sustainability strategy. Computers in Industry, 108, 178-185.

Savona, M., Cainelli, G., \& Evangelista, R. (2006). Innovation and economic performance in services. A firm level analysis. Cambridge Journal of Economics, 30(3), 435-458.

Schaltegger, S., \& Burritt, R. L. (2010). Sustainability accounting for companies: Catchphrase or decision support for business leaders? Journal of World Business, 45(4), 375-384.

Schaltegger, S., \& Wagner, M. (2011). Sustainable entrepreneurship and sustainability innovation: Categories and interactions. Business Strategy and the Environment, 20(4), 222-237.

Schneider, B., Brief, A. P., \& Guzzo, R. A. (1996). Creating a climate and culture for sustainable organizational change. Organizational Dynamics, 24(4), 7-19.

Schwartz, C. E., \& Sendor, R. M. (1999). Helping others helps oneself: Response shift effects in peer support. Social Science \& Medicine, 48(11), 1563-1575.

Schyns, P., \& Boelhouwer, J. (2004). The state of the city Amsterdam monitor: Measuring quality of life in Amsterdam. In Community Quality-of-Life Indicators (pp. 133-152): CITY?: Springer.

Seelos, C., \& Mair, J. (2005). Social entrepreneurship: Creating new business models to serve the poor. Business Horizons, 48(3), 241-246.

Setboonsarng, S., \& Gregorio, E. E. (2017). Achieving sustainable development goals through organic agriculture: Empowering poor women to build the future. Retrieved from https://digitalcommons. ilr.cornell.edu/intl

Shahabadkar, P. (2012). Deployment of interpretive structural modelling methodology in supply chain management-an overview. International Journal of Industrial Engineering \& Production Research, 23(3), 195-205.

Shane, S., \& Venkataraman, S. (2000). The promise of entrepreneurship as a field of research. Academy of Management Review, 25(1), 217-226. 
Shepherd, D. A., \& Patzelt, H. (2011). The new field of sustainable entrepreneurship: Studying entrepreneurial action linking "what is to be sustained" with "what is to be developed". Entrepreneurship Theory and Practice, 35(1), 137-163.

Shumpeter, J. A. (1968). The theory of economic development: An inquiry into profits, capital, credit, interest, and business cycle. Harvard University Press.

Simon, A., Bernardo, M., Karapetrovic, S., \& Casadesús, M. (2011). Integration of standardized environmental and quality management systems audits. Journal of Cleaner Production, 19(17-18), 20572065.

Smith, N. C., \& Lenssen, G. (2008). Mainstreaming corporate responsibility: An introduction to the special issue. Journal of Business Ethics Education, 5, 59-62.

Stuber, J. M. (2009). Class, culture, and participation in the collegiate extra curriculum. Paper presented at the Sociological Forum, 24(4),877900.

Svensson, G., Wagner, B., Asif, M., Searcy, C., Zutshi, A., \& Ahmad, N. (2011). An integrated management systems approach to corporate sustainability. European Business Review. 23(4), 353-367.

Thornbush, M. (2017). Physical geography and environmental sustainability. Sustainability, MDPI, Open Access Journal, 9(12), 1-5.

Thurik, R., \& Wennekers, S. (2004). Entrepreneurship, small business and economic growth. Journal of Small Business and Enterprise Development, 11(1), 140-149.

Tilley, F., \& Parrish, B. D. (2006). From poles to wholes: Facilitating an integrated approach to sustainable entrepreneurship. World Review of Entrepreneurship, Management and Sustainable Development, 2(4), 281-294.

Trudeau, D. (2018). Integrating social equity in sustainable development practice: Institutional commitments and patient capital. Sustainable Cities and Society, 41, 601-610.

Urbano, D., Toledano, N., \& Soriano, D. R. (2010). Analyzing social entrepreneurship from an institutional perspective: Evidence from Spain. Journal of Social Entrepreneurship, 1(1), 54-69.

Vallance, S., Perkins, H. C., \& Dixon, J. E. (2011). What is social sustainability? A clarification of concepts. Geoforum, 42(3), 342348.

van Dam, K., Schipper, M., \& Runhaar, P. (2010). Developing a competencybased framework for teachers' entrepreneurial behaviour. Teaching and Teacher Education, 26(4), 965-971. 
Vegholm, F. (2011). Relationship marketing and the management of corporate image in the bank-SME relationship. Management Research Review, 34(3), 325-336.

Warfield, J. N. (1976). Societal systems: Planning, policy and complexity. New York: John Wiley.

Wennekers, S., Van Stel, A., Carree, M., \& Thurik, R. (2010). The relationship between entrepreneurship and economic development: Is it U-shaped? Foundations and Trends in Entrepreneurship, 6(3), 167-237.

Widya-Hastuti, A., Talib, N. B. A., Wong, K. Y., \& Mardani, A. (2016). The role of intrapreneurship for sustainable innovation through process innovation in small and medium-sized enterprises: A conceptual framework. International Journal of Economics and Financial Issues, 6(3S), 83-91.

Wiesner, R., Chadee, D., \& Best, P. (2018). Managing change toward environmental sustainability: A conceptual model in small and medium enterprises. Organization \& Environment, 31(2), 152-177.

York, J. G., \& Venkataraman, S. (2010). The entrepreneur-environment nexus: Uncertainty, innovation, and allocation. Journal of Business Venturing, 25(5), 449-463.

Yu, C., Mannan, A. M., Yvone, G. M., Ross, K. N., Zhang, Y.-L., Marton, M. A., Tamayo, P. (2016). High-throughput identification of genotypespecific cancer vulnerabilities in mixtures of barcoded tumor cell lines. Nature Biotechnology, 34(4), 419.

Zahra S. A. (2005) Entrepreneurship and disciplinary scholarship: Return to the fountainhead. In Alvarez S. A., Agarwal, R., Sorenson, O. (Eds), Handbook of entrepreneurship research. International Handbook Series on Entrepreneurship, Vol 2. Springer, Boston, MA. https:// doi.org/10.1007/0-387-23622-8_12

Zerbe Jr, R. O., \& McCurdy, H. (2000). The end of market failure. University of Washington.

Zhao, F. (2005). Exploring the synergy between entrepreneurship and innovation. International Journal of Entrepreneurial Behavior \& Research, 11(1), 25-41. 